\title{
Perceived Benefits and Challeges of IFRS Adoption in Ghana: Views of Members of Institute of Chartered Accountants, Ghana (ICAG)
}

\author{
Mbawuni, Joseph ${ }^{1}$ \\ ${ }^{1}$ Department of Accounting Studies Education, University of Education, Winneba, Ghana \\ Correspondence: Mbawuni, Joseph, Department of Accounting Studies Education, University of Education, Winneba \\ Box 1277, KUMASI, Ghana. Tel: 233-243-911-000.
}

Received: November 9, 2017

Accepted: December 4, 2017 Online Published: December 10, 2017

doi:10.5430/ijfr.v9n1p99

URL: https://doi.org/10.5430/ijfr.v9n1p99

\begin{abstract}
This paper provides an empirical evidence regarding the perceived benefits and challenges of International Financial Reporting Standard (IFRS) adoption in Ghana. It draws on rich body of knowledge in IFRS from both developed and developing countries to develop a conceptual framework for the perceived benefits and challenges that come with IFRS adoption. It used data from a cross-section of 762 members of the Institute of Charted Accountants, Ghana. This study found that a number of perceived benefits and challenges with the adoption of IFRS in Ghana, notable among the benefits was the ease of comparability of financial data across borders, and the top-most challenge was the continuous amendments to IFRS. There were few differences in evaluation between old and young accountants among the respondents. The theoretical and managerial implications are discussed. This study contributes to the limited empirical research regarding the perceived benefits and challenges of IFRS adoption in Sub-Saharan African in general and Ghana in particular.
\end{abstract}

Keywords: IFRS adoption, chartered accountants, financial reporting, Ghana

\section{Introduction}

The effective management and governance of a nation's accounting system requires effective assessment and evaluation of its existing accounting practices (Judge, Li, \& Pinsker, 2010; Singh \& Newberry, 2008). The cost-benefit analysis tool has proven beneficial to all strategic management and accountants over the years. Therefore, it becomes critical for countries adopting the International Financial Reporting Standard (IFRS) to take stock of the perceived benefits and challenges that come with IFRS adoption from stakeholders' perspective in order to effectively manage the accounting system of a nation as has been done in past studies (Samaha \& Khlif, 2016). Specifically, such analysis help determine the worth of institutional compliance or conformity to institutional norms of acceptable international accounting behaviour or practice (Ramanna \& Sletten, 2014).

IFRS has been adopted in many nations as an important tool for standardising international accounting principles and financial reporting in both developed and developing countries (Owolabi \& Iyoha, 2012; Hail, Leuz, \& Wysocki, 2010; Ramanna \& Sletten, 2014). Among the Sub-Saharan Africa countries, Ghana was among the first to adopt the IFRS. At present Ghana is among fifteen countries in Africa, with the likes of Botswana, Egypt, Ethiopia, Kenya, Lesotho, Malawi, Mauritius, Mozambique, Namibia, Sierra Leone, South Africa, Tanzania, Zimbabwe, Swaziland and Uganda, to have adopted or converged to IFRS (Zori, 2011; PricewaterhouseCoopers, 2010).

Ghana adopted IFRS in place of the Ghana National Accounting standards (GNAS) on 1st January 2007. This was a strategic move towards promoting accelerated growth of the economy through private sector-led growth. The Institute of Chartered Accountants, Ghana (ICAG), has been one of the most influential stakeholders in the promotion, adoption and implementation monitoring of the IFRS in Ghana. On 23rd January, 2007 the ICAG officially launched the adoption of the IFRS and required all listed companies, public entities, banks, and insurance companies to comply with IFRS by 31st December, 2007, while other business entities were mandated to comply with IFRS within two years of its adoption in Ghana (United Nations, 2007).

Since the implementation of the IFRS in both developed and developing countries, there has been a growing interest in research in IFRS adoption and compliance among scholars and practitioners in the literature. In developing countries including Ghana, several research work has been done to enhance understanding of the IFRS adoption. For 
example, there is some research on the suitability of IFRS for Small and Medium-sized Entities (IFRS for SMES) in Ghana (Aboagye-Otchere \& Agbeibor, 2012), compliance with IFRS by business entities in Ghana (Amoako \& Asante, 2012; Ocansey \& Enahoro, 2014; Yiadom \& Atsunyo, 2014), the extent of financial statement disclosure in line with IFRS (Agyei-Mensah, 2012; Agyei-Mensah, 2013), the application of IFRS in specific countries such as Romania (Săcărin, Bunea \& Gîrbină, 2013), Nigeria (Odia \& Ogiedu, 2013), Lybia (Zakari, 2014), India (Kapoor \& Ruhela, 2013) among others.

In spite of these great strides by past researchers, a careful examination of the literature on IFRS in developing countries, especially Africa and Ghana, reveals a surprising gap in the literature regarding country-specific analysis of perceived benefits and challenges of IFRS adoption in Ghana from stakeholders' perspective in general, and from chartered accountants perspective in particular. In particular, Samaha and Khlif (2016) observe that, compared to developed countries, IFRS research remain under-researched in developing countries. In this regard, while past studies have focused on IFRS compliance and disclosures in African countries (Odia \& Ogiedu, 2013; Zakari, 2014; Aboagye-Otchere \& Agbeibor, 2012; Agyei-Mensah, 2012; Agyei-Mensah, 2013), very little research has been done regarding the perceived benefits and challenges of IFRS adoption in specific developing African countries such as Ghana (e.g., Boateng, Arhin and Afful, 2014; Odia, \& Ogiedu, 2013; Owolabi and Iyoha, 2012; Zakari, 2014). In particular, Owolabi and Iyoha (2012) attempted to explore the perceived benefits and challenges in IFRS adoption in Africa, however they failed to report country representation in the composition of the sample of users or preparers of financial reports used, neither did the authors show country-specific analysis to show comparative analysis. In Ghana, Boateng et al. (2014) provided a very limited study into benefits and challenges of IFRS adoption in Ghana using the views of only 18 professional accountants.

It, therefore, becomes critically important to study the perceived benefits and challenges of IFRS adoption from a broader perspective, using country-specific data in order to provide specific strategic directions for Ghana, and advance the financial reporting literature for developing countries in general and Ghana in particular. Moreover, despite the strategic position and significant role the ICAG plays as an important stakeholder in implementation and compliance with accounting standards in general, and IFRS adoption in Ghana since 2007, there has not been a major empirical study, as far as the researcher knows, that has examined the views of ICAG members, especially regarding the perceived benefits and challenges of IFRS adoption in Ghana. The ICAG continues to be a strong IFRS regulator and facilitator of IFRS implementation in Ghana, and their views are crucial to understanding IFRS adoption in Ghana and management of accounting practices in Ghana.

This study will contribute to the IFRS literature by providing some of the first empirical study on the perceived benefits and challenges of IFRS adoption in Ghana, and especially, from the views of members of ICAG as a key stakeholder of IFRS. Therefore, the main purpose of this paper is to examine the view of chartered accountants from ICAG regarding the perceived benefits and challenges of IFRS adoption in Ghana since its implementation in 2007. This study is guided by the following specific objectives:

1. To examine the perceived benefits of IFRS adoption in Ghana since its implementation in 2007.

2. To examine the perceived challenges of IFRS adoption in Ghana since its implementation in 2007.

3. To determine differences between young and old accounting professionals in ICAG in their evaluation of perceived benefits and challenges of IFRS adoption in Ghana.

The rest of the paper is organised as follows: section two focuses on a review of literature, section three is the methodology, section four is the results of the study, section five is the implications, and section six is the limitations and conclusion of the study.

\section{Literture Review and Conceptual Framework}

\subsection{Institutional Theory of IFRS Adoption}

Many past studies have attempted to explain institutional adoption of international accounting standard (IAS) through the lens of institutional theory (e.g., Carpenter \& Feroz, 2001; Zaman Mir \& Shiraz Rahaman, 2005; Judge, Li \& Pinsker, 2010; Aboagye-Otchere \& Agbeibor, 2012). According to institutional theorists, organisations must conform to societal norms of acceptable practice in order to benefit from the continuous support they require for survival from their relevant stakeholders (Covaleski \& Dirsmith, 1995; Judge, Li \& Pinsker, 2010). These isomorphic pressures can be described as coercive, normative and mimetic. Coercive isomorphic pressures are derived from the influence of political and regulatory systems that are exerted by global network of multinational corporations on which organisations depend for critical resources and long-term survival (Guler et al., 2002). In the case of adoption of international accounting standard by nations, coercive pressures may arise from the World Bank 
and capital markets.

Normative isomorphic pressures refer to collective values that bring about conformity of thought and deed within institutional environments (DiMaggio \& Powell, 1991). These collective values allow for smooth inter-organisational networks and continual partnership in specified professional areas (Haunschild, 1993). One such values is the need for similar accounting education attainment for all international accounting professionals for continual partnership in the accounting profession by organisations (Haunschild, 1993).

Mimetic isomorphic pressures describe the tendency of social actors to imitate successful and legitimate social actors such as organisations and individuals (DiMaggio \& Powell, 1983). In this regard, previous research has found that a region's openness to foreign competition and trade exposes organisations to imitations in social norms of best practices (Wei, Liu, Song, \& Romilly, 2001). Similarly, Guler et al. (2002) found association between foreign direct investment (FDI) and the adoption of international accounting standards within a nation. Thus, mimetic pressures may arise from collaborating with relevant trade partners and multinational corporations as has been described as network effects in IFRS adoption (Ramanna \& Sletten, 2014).

These institutional pressures are significantly felt by developing and emerging economies as they frequently rely or desire to seek foreign direct investment and other resources from developed countries and international organisations. Embedded in the institutional theory is the network benefits that weaker institutions would derive from conforming to the social norms of stronger institutions (Ramanna \& Sletten, 2014). This means countries adopting IFRS would derive some legitimate benefits within the institutional network of International Accounting Standards Board (IASB) (Ramanna \& Sletten, 2014). In effect, the institutional theory enables us to understand that some actors like Ghana would adopt and conform to IFRS as acceptable norm of accounting practice for its business entities due to the perceived benefits of IFRS to its users or stakeholders in Ghana (Judge et al., 2010). In this regard, the normative pressures enable Ghana to adopt IFRS in order to conform to the norms of global accounting standards and share the collective value it brings towards all nations involved. At the same time, Ghana's openness to foreign competition and trade exposes her business entities to mimetic isomorphic pressures to imitate social norms of best accounting practices, like IFRS adoption, of trade partners.

\subsection{Benefits of IFRS to Stakeholders}

The adoption of IFRS is expected to benefit all social actors or stakeholders within the institutional network of International Accounting Standards Board (IASB) (Ramanna \& Sletten, 2014). These stakeholders include users of accounting and financial information such as national agencies, business organisations, investors, policy makers, regulators, customers, among others. As countries adopt IFRS, it becomes necessary to take stock of the perceived benefits and challenges that come with the adoption of IFRS in order to effectively manage the national accounting system of a nation. This will help determine the worth of institutional compliance or conformity to institutional norms of acceptable behaviour or practice (Ramanna \& Sletten, 2014) such as the adoption of the IFRS. In view of this, this study is critically important to practitioners and regulators of IFRS in Ghana to judge the worth of their conformance to IASB institutional network.

To nations, the legitimate benefits of IFRS adoption include the credibility to compete for FDI in world capital markets, greater mobility of capital at a decreased cost, more efficient allocation of resources, improved quality of financial reporting, and avoidance of the necessity of having to develop national accounting standards (Ramanna \& Sletten, 2014). Sunder (2010) proposes six perceived legitimate benefits for IFRS adoption as contribution to prosperity and wealth of society, inclusion of relevant information from all parts of the economy, stability over time, adaptability to changes in economic environment, robustness against manipulations, and resistance to capture by narrow interest groups.

To business organisations, the adoption of IFRS will result in greater transparency and understandability, reduced the cost of capital to organisations, reduced national standard-setting costs, (Leuz \&Verrecchiia, 2008; Daske, Hail, Leuz \& Verdi, 2008; Odia \& Ogiedu, 2013), enhance efficient capital allocation (Bushman \& Piotroski, 2006), wider market development (Ahmed \& Duellman, 2011), improved and higher market liquidity and value (Mihai, Ionaşcu, \& Ionaşcu, 2012), boosted comparability (DeFond, Hu, Hung, \& Li, 2011; Săcărin, Bunea \& Gîrbină, 2013), enhanced transparency of results (Daske et al., 2008) and facilitated cross border movement of capital (Bhattacharjee \& Hossain 2010; Mihai et al., 2012). Others include easier comparability of financial data across borders and access to investment opportunities, increased credibility of domestic markets to foreign capital providers and potentials foreign merger partners (Bhattacharjee \& Hossain 2010; Madawaki, 2014). It will also facilitate easier international mobility of professional staffs across national boundaries (Odia \& Ogiedu, 2013; Owolabi \& Iyoha, 2012). For the multinational companies, it will help them to fulfill the disclosure requirement for stock exchanges 
around the world (Daske et al., 2008; Odia \& Ogiedu, 2013; Owolabi \& Iyoha, 2012; Ramanna \& Sletten, 2014).

To investors, the adoption of IFRS would result in higher quality information for investors for investment decisions (Barth, Landsman \& Lang, 2008; Florou \& Pope, 2012), more confidence in the information presented, better understanding of risk and return, companies can be compared to a peer group of companies, more timely financial reports, easier access to financial reporting, among others (Ahmed \& Duellman, 2011; Ball, 2006; Barth et al., 2008). To policy makers, the adoption of IFRS could result in strengthened and more effective capital market, better access to the global capital markets, promotion of cross-border investment, better information for control and decision-making purposes, more realistic planning experiences, among others. To industry regulators, the adoption of IFRS could result in improved regulatory oversight and enforcement, a higher standard of financial disclosure, better information for market participants, stronger ability to attract and monitor listings by foreign companies, among others (Owolabi \& Iyoha, 2012).

\subsection{Challenges of Institutional Adoption of IFRS}

In past studies, many challenges have been identified as teething issues facing the adoption of IFRS by nations and business organisations (e.g., Florou \& Pope, 2012; Kapoor \& Ruhela, 2013; Monisola, 2013; Owolabi \& Iyoha, 2012; Zakari, 2014). First, there is a challenge of user awareness and adequate knowledge of IFRS. Related to this is the challenge of adequate training of relevant professionals in preparing financial statements according to the IFRS (Alp \& Ustundag, 2009; Kapoor \& Ruhela, 2013; Owolabi \& Iyoha, 2012). Also there is the challenge of changes of legal system from the use of local accounting laws to the use of IFRS (Kapoor \& Ruhela, 2013; Li, 2010). Other challenges include enforcement and compliance mechanism (Kapoor \& Ruhela, 2013; Martins, 2011), funding of conversion, complexity of conversion, retention of key employees, ethical business environment, timely interpretation of standards (Owolabi \& Iyoha, 2012). Bohušová and Blašková (2011) and others (e.g., Mulyadi, Soepriyanto, \& Anwar, 2012; Odia \& Ogiedu, 2013; Zakari, 2014) indicated that, IFRS implementation for SMEs could be more challenging especially in taxation and capital maintenance rules, especially within a complex tax system. In addition, the application of IFRS is more challenging in developing countries (United Nations, 2008) and countries which did not developed their own accounting standards (Bohušová \& Blašková, 2011) than in developed countries which developed their own standards.

\subsection{Adoption IFRS in Ghana}

\subsubsection{Role of ICAG}

In 1999, the ICAG strongly facilitated the compliance of all companies in Ghana with the international Accounting Standards (IAS). Then on 1 January 2007, the ICAG announced Ghana's readiness to adopt the new IFRS in Ghana as part of her efforts to promote accelerated growth of the economy through private sector-led growth. This was to replace its out-dated Ghana National Accounting standards (GNAS). The council of ICAG formally launched the adoption of IFRS on 23rd January, 2007 and required all listed companies, public entities, banks, and insurance companies to comply with IFRS as at 31st December, 2007 and other entities were given an additional transition period of two years to comply (United Nations, 2007).

\subsubsection{Empirical Review of IFRS Research in Ghana}

The following section reviews some research conducted in the area of IFRS adoption in Ghana.

Aboagye-Otchere and Agbeibor (2012) studied the suitability of IFRS for Small and Medium-sized Enterprises (IFRS for SMES) or small businesses in Ghana. Their purpose was to establish the need for the IFRS for SMEs and the appropriateness of the IFRS for SMEs as the accounting standard of choice for small businesses in Ghana. They also investigated firm characteristics that are likely to influence small businesses' need for IFRS and the appropriateness of the Standard for small businesses. Through a survey of 305 small businesses, the authors found that small businesses in Ghana have limited international structures and activities which do not result in a need for internationally comparable financial reporting information. Also, they found that small businesses did not receive requests to provide such information. In total, 19 of the 27 issues addressed by the Standard and assessed in the study were found to be irrelevant to small businesses in Ghana. Moreover, they found size, legal form and number of owners as key factors that influence the suitability of the Standard for small businesses in Ghana.

Amoako and Asante (2012) studied the extent of compliance of listed banks in Ghana with IFRS, with particular reference to financial instruments, IFRS 7. The authors measured level of mandatory compliance with IFRS 7 using a mandatory disclosure index (MDI) from a self-constructed compliance checklist. Using data from a sample of six listed banks from 2008 to 2009 based on the published annual reports and audited financial statements of the banks, the overall results showed a high degree of compliance with IFRS 7, though not absolute. The results of their study 
showed that, comparatively, all the banks improved upon the IFRS 7 required compliance level, scoring $98 \%$ to $100 \%$ average compliance level for both 2008 and 2009. They claim that what might have accounted for this trend was that the management and staff of the Ghanaian banks are now getting more familiar with the IFRS in 2009 than in 2008 and that has reflected in the improved performance with the IFRS 7 disclosure requirement. Moreover, they maintained that, IFRS 7 compliance by the listed banks might have resulted partly from two factors. Firstly, the monitoring and enforcement mechanisms put in place by the Bank of Ghana is very effective. The other reason is that, five of the banks have as their auditor an accounting firm that belongs to the "Big 5", which Hodgdon (2009) found was positively related to compliance level.

Moreover, Agyei-Mensah (2012) investigated the extent of disclosure by firms complying with IAS 1. The key relationships examined are the relationship between level of disclosure and company size, profitability, liquidity, leverage and auditor size. The results showed that the disclosure level, mean of 60.9\%, indicate that most of the firms listed on the Ghana Stock Exchange did not overwhelmingly comply with the IAS 1 disclosure requirements. The result showed that only liquidity was associated with the extent of disclosure. The results did not provide support for a positive relationship between company size, profitability, leverage and auditor size.

Furthermore, Agyei-Mensah (2013) also studied the adoption of (IFRS) in Ghana and the quality of financial statement disclosures. The author investigated the quality of financial reports before and after adopting IFRSs in Ghana, and also the influence of firm-specific characteristics which include firm size, profitability, debt equity ratio, liquidity and audit firm size on the quality of financial information disclosed by firms listed on the Ghana Stock Exchange. The research was conducted through detailed analysis of financial statements for the pre-official adoption period (2006) and post adoption period (2008) of the listed firms. Through regression analysis, the results of the quality of financial information disclosure mean of $76.80 \%$ (pre adoption) and $87.09 \%$ (post adoption) for the two years indicate that the quality of financial reports has improved significantly after adopting IFRSs. The findings confirmed that the implementation of IFRSs generally reinforce accounting disclosure quality. It also indicated overwhelming compliance of listed firms with the IFRS framework.

Ocansey and Enahoro (2014) explored a comparative study of IFRS implementation in Ghana and Nigeria. They found the absence of certain standards in Ghana and Nigeria's national accounting standards in areas of accounting for government grants and disclosure of government assistance, borrowing cost, impairment of assets, intangible assets, financial reporting in hyperinflationary economies, first-time adoption of international financial reporting standards, non-current assets held for sale and discontinued operations, accounting and reporting by retirement benefit plan, share based payments, events after reporting date, related party disclosure and accounting for agriculture. However, the authors found that the two countries accounting standards were different in the treatments of the disclosure of capital surplus and income surplus, the effect of certain changes in accounting policies, deferred tax assets and liabilities, accounting for intangibles, dividend declared pending ratification and basis for segment accounting.

Yiadom and Atsunyo (2014) examined compliance with IFRS by 31 listed companies in Ghana. This study examined the extent to which companies listed on the Ghana Stock Exchange (GSE) comply with IFRS presentation and disclosure requirement. With the aid of a checklist, an index of compliance was devised to quantify the level of compliance. This was applied to the 2010 financial statement of 31 companies listed on the GSE. They analysed the extent of compliance by companies categorised in line with industry classification of the GSE and found an overall mean compliance of $85.8 \%$ in Ghana. The study further examined relationships between company attributes and the extent of compliance. Using ANOVA, they found statistically significant differences between industry types and compliance extent and rate. Company attributes of size, profitability, auditor type, internationality and industry type associate positively with IFRSs compliance. The study recommended that the ICAG should liaise with regulators to organise regular training programmes for companies to provide a practical guide for full compliance since the IFRS receive continuous amendment.

Boateng et al. (2014) provided a pilot exploratory study into the benefits and challenges of IFRS adoption in Ghana using data from only 18 professional accountants from listed firms on the Ghana Stock Exchange. Their study revealed that IFRS improved the access of local companies to international markets, helped local firms to gain credibility, transparency, acceptance and consolidation. They also found that some local firms face challenges such as complexity of the application of IFRS, lack of qualified personnel and additional operational cost. Obviously their study was very limited in sample used and the content of proposed benefits and challenges of IFRS faced by local firms. The present study seeks to widen the scope and content of empirical research into the perceived benefits and challenges of IFRS adoption in Ghana, and provide more detailed analysis of empirical findings with emphasis on 
theoretical and practical implications as well as policy directions for national regulators.

\subsubsection{The Main Research Gap}

As already mentioned, despite the strategic position and significant role the ICAG plays as an important stakeholder in IAS compliance in Ghana and in the implementation of IFRS in Ghana, very little empirical research has been done to highlight the views of ICAG members regarding perceived benefits and challenges of IFRS adoption in Ghana since its adoption in 2007. This study hopes to contribute to filling this void in the IFRS research in Ghana.

\subsection{Conceptual Framework}

Based on the theoretical background and literature reviewed, a conceptual framework was developed for this study (Figure 1). It depicts the dimensions of perceived benefits and challenges of IFRS implementation by accounting profession in the ICAG. The perceived benefits dimensions include perceived benefits of IFRS adoption to companies, policy makers, investors, and industry regulators (e.g., Odia \& Ogiedu, 2013; Owolabi \& Iyoha, 2012; Mihai, Ionaşcu, \& Ionaşcu, 2012; Ramanna \& Sletten, 2014; Săcărin, Bunea \& Gîrbină, 2013). The perceived challenges were based on the literature reviewed (e.g., Odia \& Ogiedu, 2013; Owolabi \& Iyoha, 2012; Zakari, 2014 Florou \& Pope, 2012; Monisola, 2013; Bohušová \& Blašková, 2011).

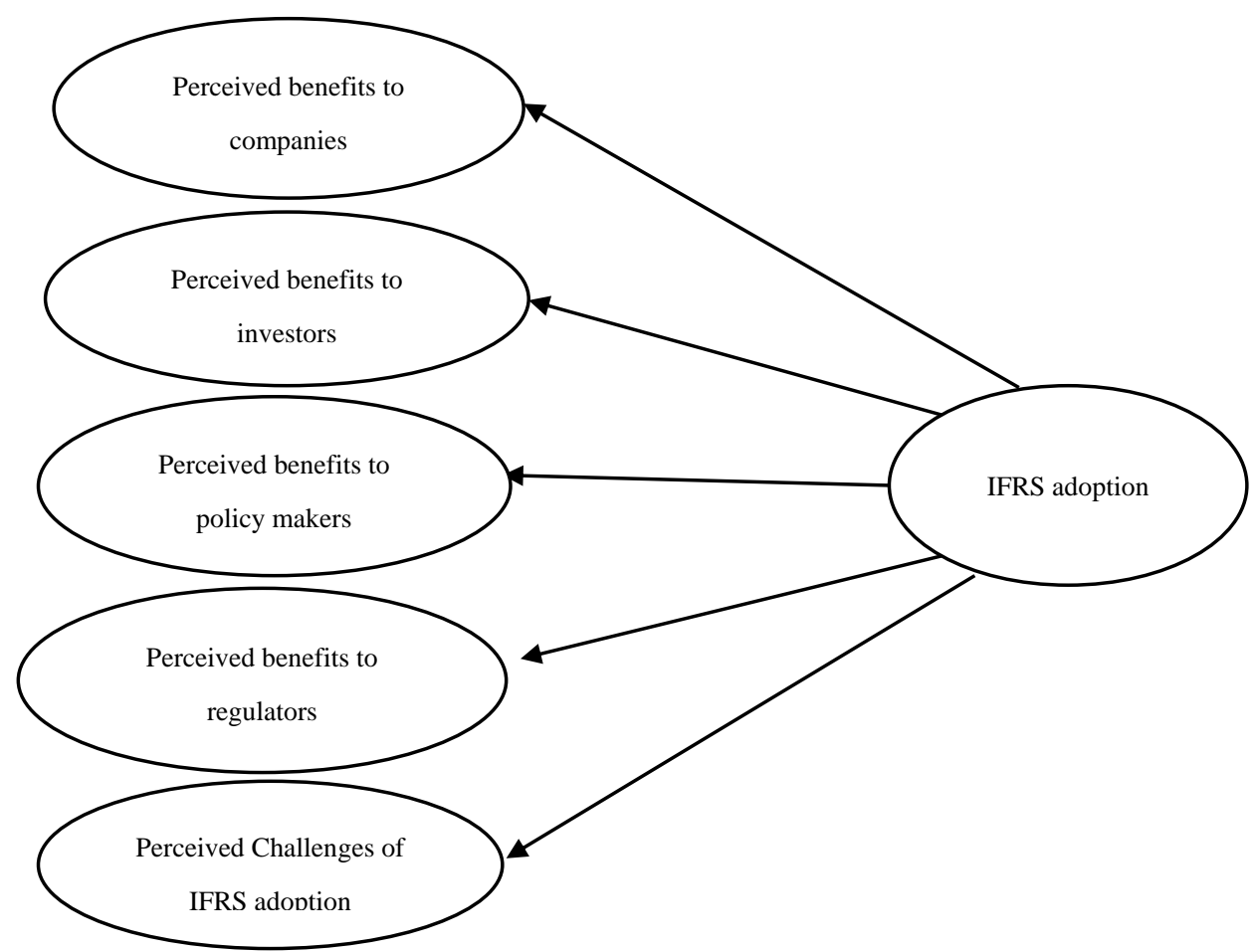

Figure 1. Conceptual framework

\section{Method}

\subsection{Rationale for Choice of Context}

This research was conducted in Ghana. Ghana is chosen for two important reasons. First, there is strong stakeholders' interest for the practical relevance of IFRS in Ghana as well as its challenges since its adoption in 2007. The ICAG, as one of the key implementation stakeholders, would need to be involved in the evaluation of the perceived benefits and challenges of IFRS in Ghana. Second, Ghana is one of the fastest growing emerging countries in the Sub-Saharan Africa (SSA), and offers enormous international business opportunities for the multi-national companies adopting IFRS in other countries. These reasons make Ghana an interesting research context to scholars and business practitioners in the areas of management of Ghanaian accounting systems and IFRS adoption.

\subsection{Research Design, Population and Sampling}

This study was a cross-sectional survey that sought to collect field data on chartered accountants' perception of the 
benefits and challenges of IFRS adoption in Ghana. This was meant to provide a general descriptive analysis for an initial study (Hair et al., 2010). The population for the study comprised 4005 chartered accountants who are good-standing members of ICAG as at May 2016, who practice accounting and auditing services for various business entities in Ghana. These practicing chartered accountants were chosen because they represent the ICAG. Of the 4005, a sample of 762 ICAG members were chosen based on their attendance to the 2016 Annual Accountants' Conference held on 26th May 2016 at the Moevenpick Ambassador Hotel, Accra. Thus, a purposive sample size of 762 respondents was chosen for the study because they constitute active ICAG members in good standing. Also, it was easy collecting data from the respondents because they were all converged at one point in time.

\subsection{Development of Research Instrument/Measures}

A self-administered, structured questionnaire was developed based on past empirical research on perceived benefits and challenges identified with the adoption of IFRS (e.g., Bohušová \& Blašková, 2011; Odia \& Ogiedu, 2013; Okundi, 2013; Owolabi \& Iyoha, 2012; Ramanna \& Sletten, 2014; Sunder, 2010; Zakari, 2014). It consisted of four sections regarding the perceived IFRS benefits to companies, policy makers, investors, and industry regulators. It also had a section for the perceived challenges of IFRS adoption in Ghana, and a section for capturing respondents' profile such as gender, age, education, income levels and number of clients' respondents provide accounting services for. A five-point Likert scale was used to measure variables for the research constructs since previous studies recommend the use of five-point likert scale because it has strong predictive power like seven-point Likert scale (e.g., Danaher and Haddrell, 1996). The Likert scale ranged from strongly disagree to strongly agree, coded 1 to 5 respectively.

\subsection{Administration of Research Instrument}

The questionnaire was pre-tested and finally administered to the target population. Specifically, the questionnaire were administered at the Annual Accountants' Conference held 26th May 2016 at the Moevenpick Ambassador Hotel, Accra. We used an informed consent form to seek permission from the respondents and assured them of anonymity and confidentiality of their responses. Out of the 762 questionnaires administered, the survey yielded 584 usable questionnaires, representing $76.6 \%$ response rate. This is considered a high response rate for survey research of this nature (Hair et al., 2010).

\subsection{Reliability of Research Instrument}

Cronbach alpha reliability co-efficients for the five sub-dimensions are presented in Table 1.

Table 1. Reliability analysis for research constructs and variables

\begin{tabular}{lll}
\hline Dimensions of IFRS & No. of items & Cronbach's Alpha \\
\hline Perceived benefits to companies & 20 & 0.914 \\
Perceived benefits to investors & 6 & 0.866 \\
Perceived benefits to policy makers & 5 & 0.847 \\
Perceived benefits to regulators & 4 & 0.865 \\
All perceived benefit items & 35 & 0.955 \\
Perceived Challenges of IFRS adoption & 13 & 0.855
\end{tabular}

Note: Cronbach alpha reliability co-efficient, 0.70 is acceptable threshold (Straub, 2004; Hair et al., 2010).

They range from 0.847 to 0.914 , with a composite alpha of 0.955 for all perceived benefit items and 0.855 for perceived challenges dimension. All the Cronbach's alphas for the IFRS dimensions exceeded the recommended 0.70 for social science research (Straub et al., 2004). This indicates good reliability of the research instrument.

\section{Data Analysis Tool}

A descriptive analysis was conducted to describe respondents' ratings for the perceived benefits and challenges of IFRS adoption by accounting professionals in ICAG. A non-parametric K-Wallis ANOVA analysis was conducted to reveal differences in respondents' evaluation based on age due to the descriptive focus of the study. 


\section{Results of Study}

First, we present results on respondents' profile (section 5.1) and then those for addressing the research objectives (section 5.2).

\subsection{Results for Perceived Benefits of IFRS Adoption in Ghana}

The results for perceived benefits of IFRS adoption in Ghana together with results on age differences are presented in Tables 2, 3 and 4. Then results on challenges of IFRS adoption are presented in Table 5.

Table 2. Respondents' evaluation of perceived benefits of IFRS adoption to companies

\begin{tabular}{|c|c|c|c|c|c|c|}
\hline \multirow[t]{2}{*}{$\mathrm{S} / \mathrm{n}$} & \multirow[t]{2}{*}{ Dimensions of IFRS evaluation } & \multirow[t]{2}{*}{$\begin{array}{l}\text { Overall } \\
\text { Mean }\end{array}$} & \multirow[t]{2}{*}{$\begin{array}{l}\text { Young } \\
<46 y r s \\
(n=336)\end{array}$} & \multirow[t]{2}{*}{$\begin{array}{l}\text { Old } \\
>46 \text { yrs } \\
(n=248)\end{array}$} & \multicolumn{2}{|c|}{$\begin{array}{l}\text { Group } \\
\text { Difference } \\
\text { Analysis } \\
(\mathbf{D f}=\mathbf{1})\end{array}$} \\
\hline & & & & & & Sign. \\
\hline & $\begin{array}{l}\text { Perceived Benefits to Companies. Adoption of } \\
\text { IFRS led to: }\end{array}$ & & & & & \\
\hline 1. & $\begin{array}{l}\text { Easier comparability of financial data across } \\
\text { borders }\end{array}$ & 4.29 & 292.15 & 292.98 & 0.004 & 0.949 \\
\hline 2. & Elimination of multiple reporting standards & 4.28 & 301.18 & 275.31 & 5.387 & $0.020 *$ \\
\hline 3. & Better Quality of Financial Reporting & 4.25 & 299.12 & 283.52 & 1.499 & 0.221 \\
\hline 4. & $\begin{array}{l}\text { Facilitating easier international mobility of } \\
\text { professional staffs across national boundaries. }\end{array}$ & 4.12 & 306.80 & 273.12 & 6.666 & $0.010^{*}$ \\
\hline 5. & $\begin{array}{l}\text { Greater transparency and understandability of } \\
\text { accounting practices }\end{array}$ & 4.07 & 289.08 & 297.13 & 0.391 & 0.532 \\
\hline 6. & $\begin{array}{l}\text { Improved management information for } \\
\text { decision-making. }\end{array}$ & 4.03 & 295.48 & 288.47 & 0.314 & 0.575 \\
\hline 7. & $\begin{array}{l}\text { Better access to capital, including from foreign } \\
\text { sources }\end{array}$ & 3.97 & 311.19 & 267.18 & 11.210 & 0.001 \\
\hline 8. & Ease of regulation of securities markets & 3.96 & 288.57 & 297.82 & 0.502 & 0.479 \\
\hline 9. & $\begin{array}{l}\text { Increased credibility of domestic markets to } \\
\text { foreign capital providers and }\end{array}$ & 3.94 & 291.89 & 293.32 & 0.12 & 0.912 \\
\hline 10. & Easy cross border listing & 3.90 & 305.53 & 274.85 & 5.276 & $0.022 *$ \\
\hline 11. & Enhanced competitiveness & 3.86 & 296.83 & 286.63 & 0.603 & 0.437 \\
\hline 12. & Potentials foreign merger partners and acquisition. & 3.85 & 301.79 & 279.91 & 2.761 & 0.097 \\
\hline 13. & Reduced national standard-setting costs & 3.82 & 285.96 & 301.36 & 1.359 & 0.244 \\
\hline 14. & Greater effectiveness of the internal audit & 3.78 & 300.58 & 281.56 & & \\
\hline 15. & Better risk management & 3.77 & 290.15 & 295.68 & 0.480 & 0.488 \\
\hline 16. & Many investment opportunities, & 3.72 & 302.91 & 279.75 & 2.789 & 0.095 \\
\hline 17. & $\begin{array}{l}\text { The lower susceptibility to political pressures than } \\
\text { national standards for the multinational } \\
\text { companies, }\end{array}$ & 3.69 & 298.26 & 284.70 & 1.039 & 0.308 \\
\hline 18. & $\begin{array}{l}\text { Continuation of local implementation guidance for } \\
\text { local circumstances for the multinational } \\
\text { companies, }\end{array}$ & 3.59 & 300.08 & 282.23 & 1.879 & 0.170 \\
\hline 19. & $\begin{array}{l}\text { Lower cost of capital to companies and higher } \\
\text { share prices (due to greater confidence of investors } \\
\text { and transparent information) }\end{array}$ & 3.53 & 299.21 & 297.13 & 1.408 & 0.235 \\
\hline 20. & Lower cost of audit fees & 3.19 & 287.49 & 281.56 & 0.774 & 0.379 \\
\hline
\end{tabular}

Source: Field data, 2016, scale: 1- strongly disagree, 2- agree, 3- neutral, 4 - agree, 5 - strongly agree

For the perceived benefits of IFRS adoption in Table 2, the results show that, to companies, the most rated perceived benefits of IFRS adoption is that it has led to easier comparability of financial data across borders (mean $=4.29$ ). This is followed by the elimination of multiple reporting standards (mean $=4.28$ ), better quality of financial 
reporting (mean

$=4.25)$, facilitating easier international mobility of professional staffs across national boundaries (mean $=4.12$ ), greater transparency and understandability of accounting practices (mean $=4.07$ ), improved management information for decision-making (mean $=4.03$ ) and better access to capital, including from foreign sources (mean=3.97). The least rated perceived benefits are lower cost of capital to companies and higher share prices (due to greater confidence of investors and transparent information) (mean = 3.53) and lower cost of audit fees (mean=3.19).

In terms of the difference, there were only three areas of differences between young and old respondents. Young accountants (mean rank $=301.18$ ) rated their evaluation of the elimination of multiple reporting standards significantly higher than old accountants (mean rank $=275.31, \mathrm{p}=0.020, \mathrm{H}=5.387$ ). Again, in terms of IFRS facilitating easier international mobility of professional staffs across national boundaries, young accountants rated it significantly higher (mean $=306.80$ ), than old accountants (mean rank $=273.12, \mathrm{p}=0.010, \mathrm{H}=6.666$ ). Finally, in terms of IFRS adoption easing cross border listing, younger accountants rated it significantly higher $($ mean $=305.53)$ than old accountants ( mean rank $=274.85, \mathrm{p}=0.022, \mathrm{H}=5.276$ ).

Table 3. Respondents' evaluation of perceived benefits of IFRS adoption to investors

\begin{tabular}{|c|c|c|c|c|c|c|}
\hline \multirow[t]{2}{*}{$\mathrm{S} / \mathrm{n}$} & \multirow[t]{2}{*}{ Dimensions of IFRS evaluation } & \multirow[t]{2}{*}{$\begin{array}{l}\text { Overall } \\
\text { Mean }\end{array}$} & \multirow[t]{2}{*}{$\begin{array}{l}\text { Young } \\
<46 y r s \\
(\mathrm{n}=336)\end{array}$} & \multirow[t]{2}{*}{$\begin{array}{l}\text { Old } \\
>46 \text { yrs } \\
(n=248)\end{array}$} & \multicolumn{2}{|c|}{$\begin{array}{l}\text { Group } \\
\text { Difference } \\
\text { Analysis } \\
(\mathbf{D f}=\mathbf{1})\end{array}$} \\
\hline & & & & & $\mathbf{H}$ & Sign. \\
\hline & Perceived benefits to investors. IFRS adoption has led to & & & & & \\
\hline 1. & Better information for decision-making & 4.17 & 296.24 & 287.44 & 0.48 & 0.488 \\
\hline 2. & More confidence in the information presented & 4.10 & 288.68 & 297.68 & 0.501 & 0.479 \\
\hline 3. & Companies can be compared to a peer group of companies & 4.10 & 291.68 & 291.61 & 0.022 & 0.882 \\
\hline 4. & Better understanding of risk and return & 3.68 & 291.81 & 293.61 & 0.016 & 0.9 \\
\hline 5. & More timely financial reports & 3.65 & 289.21 & 296.96 & 0.336 & 0.562 \\
\hline 6. & Easier access to financial reporting & 3.54 & 296.71 & 286.8 & 0.557 & 0.456 \\
\hline
\end{tabular}

Source: Field data, 2016, scale: 1- strongly disagree, 2- agree, 3- neutral, 4 - agree, 5 - strongly agree

From Table 3, to investors, the most rated perceived benefit of IFRS adoption is better information for decision-making (mean $=4.17$ ), followed by more confidence in the information presented $($ mean $=4.10)$, and companies can be compared to a peer group of companies (mean $=4.10)$ while the least rated items are more timely financial reports (mean $=3.65$ ) and easier access to financial reporting (mean $=3.54)$. In terms of the difference, there were no areas of significant differences between the ratings of young and old respondents.

Table 4. Respondents' evaluation of perceived benefits of IFRS adoption to policy makers

\begin{tabular}{|c|c|c|c|c|}
\hline Dimensions of IFRS evaluation & $\begin{array}{l}\text { Overall } \\
\text { Mean }\end{array}$ & $\begin{array}{l}\text { Young } \\
<46 y r s \\
(n=336)\end{array}$ & $\begin{array}{l}\text { Old } \\
>46 \text { yrs } \\
(n=248)\end{array}$ & $\begin{array}{l}\text { Group } \\
\text { Difference } \\
\text { Analysis } \\
(\mathrm{Df}=1)\end{array}$ \\
\hline & & & & H Sign. \\
\hline
\end{tabular}

\section{Perceived benefits to policy makers. Adoption of} IFRS led to

1. Better information for control and decision-making purposes

$\begin{array}{lllll}3.96 & 284.62 & 303.18 & 2.192 & 0.139 \\ 3.91 & 302.12 & 279.47 & 3.006 & 0.083 \\ 3.84 & 304.34 & 276.46 & 4.523 & 0.033^{*} \\ 3.83 & 290.53 & 295.17 & 0.127 & 0.722 \\ 3.73 & 289.16 & 297.02 & 0.373 & 0.541\end{array}$

2. Promotion of cross-border investment

- neutral, 4 - agree, 5 - strongly agree 
To policy makers, the most rated perceived benefit of IFRS adoption is better information for control and decision-making purposes (mean $=3.96$ ), followed by promotion of cross-border investment (mean $=3.91)$, better access to the global capital markets (mean $=3.84)$, strengthened and more effective capital market (mean $=3.83$ ), and more realistic planning experiences $($ mean $=3.73$ ). In terms of age difference in rating, there was only one area of difference between the ratings of young and old respondents; IFRS adoption provided better access to global capital markets. For this item, young accountants (mean rank $=304.34$ ) rated their evaluation significantly higher than old accountants (mean rank $=276.46, \mathrm{p}=0.033, \mathrm{H}=4.523$ ).

Table 5. Respondents' evaluation of perceived benefits of IFRS adoption to regulators

\begin{tabular}{|c|c|c|c|c|c|c|}
\hline $\mathrm{S} / \mathrm{n}$ & Dimensions of IFRS evaluation & $\begin{array}{l}\text { Overall } \\
\text { Mean }\end{array}$ & $\begin{array}{l}\text { Young } \\
<46 y r s \\
(\mathrm{n} \\
=336)\end{array}$ & $\begin{array}{ll}\text { Old } & \\
> & 46 \\
\text { yrs } & (n \\
=248)\end{array}$ & $\begin{array}{l}\text { Group } \\
\text { Difference } \\
\text { Analysis } \\
(\text { Df }=1) \\
\text { H }\end{array}$ & Sign. \\
\hline \multirow{5}{*}{$\begin{array}{l}1 . \\
2 . \\
3 . \\
4 .\end{array}$} & $\begin{array}{l}\text { Perceived benefits to regulators. Adoption of } \\
\text { IFRS led to: }\end{array}$ & & & & & \\
\hline & A higher standard of financial disclosure & 4.18 & 285.48 & 302.02 & 1.618 & 0.203 \\
\hline & Better information for market participants & 4.04 & 288.61 & 297.77 & 0.525 & 0.857 \\
\hline & Improved regulatory oversight and enforcement & 4.03 & 293.27 & 291.45 & 0.02 & 0.889 \\
\hline & $\begin{array}{l}\text { Better ability to attract and monitor listings by } \\
\text { foreign companies }\end{array}$ & 3.91 & 291.49 & 293.86 & 0.032 & 0.857 \\
\hline
\end{tabular}

Source: Field data, 2016, scale: 1- strongly disagree, 2- agree, 3- neutral, 4 - agree, 5 - strongly agree

To regulators, the highest rated perceived benefit was a higher standard of financial disclosure $($ mean $=4.18)$, followed by better information for market participants (mean $=4.04$ ), improved regulatory oversight and enforcement (mean $=4.03$ ), and better ability to attract and monitor listings by foreign companies (mean $=3.91)$. In terms of differences, there was no area of difference between the ratings of young and old respondents in this category of perceived benefits.

\subsection{Results for Perceived Challenges of IFRS Adoption in Ghana}

The results for perceived challenges of IFRS adoption in Ghana and results for the differences in the evaluation between young and old accountants of ICAG are presented in Tables 6 .

Table 6. Respondents' evaluation of perceived challenges of IFRS adoption in Ghana

\begin{tabular}{|c|c|c|c|c|c|c|}
\hline $\mathrm{S} / \mathrm{n}$ & Dimensions of IFRS evaluation & $\begin{array}{l}\text { Overall } \\
\text { Mean }\end{array}$ & $\begin{array}{l}\text { Young } \\
<46 \text { yrs } \\
(\mathrm{n}=336)\end{array}$ & $\begin{array}{l}\text { Old } \\
>46 \text { yrs } \\
(n=248)\end{array}$ & $\begin{array}{l}\text { Group } \\
\text { Difference } \\
\text { Analysis } \\
(\text { Df }=1) \\
\text { H }\end{array}$ & Sign. \\
\hline & Perceived Challenges of IFRS adoption in Ghana & & & & & \\
\hline 1. & Continuous amendment to IFRS & 3.84 & 287.57 & 299.19 & 0.764 & 0.382 \\
\hline 2. & Use of fair value as measurement base & 3.80 & 292.44 & 292.58 & 0.001 & 0.991 \\
\hline 3. & Training of relevant professionals & 3.79 & 275.1 & 316.08 & 9.343 & $0.002 *$ \\
\hline 4. & $\begin{array}{l}\text { Accounting knowledge and expertise possessed by } \\
\text { financial statement users }\end{array}$ & 3.74 & 280.23 & 309.13 & 4.714 & $0.030 *$ \\
\hline 5. & Compliance and enforcement & 3.73 & 284.76 & 302.99 & 1.954 & 0.162 \\
\hline 6. & Complexity of conversion & 3.71 & 285.87 & 301.48 & 1.383 & 0.24 \\
\hline 7. & Timely interpretation of standards & 3.63 & 278.2 & 311.87 & 6.483 & $0.011 *$ \\
\hline 8. & Funding of conversion & 3.60 & 274.61 & 316.74 & 9.948 & $0.002 *$ \\
\hline 9. & Ethical Business environment & 3.59 & 283.3 & 305.33 & 2.88 & 0.09 \\
\hline 10. & Retention of key employees & 3.49 & 280.3 & 309.99 & 4.669 & $0.031 *$ \\
\hline 11. & Amendment to existing laws & 3.28 & 290.1 & 302.99 & 0.261 & 0.609 \\
\hline 12. & Taxation related issues & 3.28 & 288.92 & 297.35 & 0.58 & 0.446 \\
\hline 13. & $\begin{array}{l}\text { Awareness of International Financial Reporting } \\
\text { Practices }\end{array}$ & 3.13 & 281.07 & 307.99 & 9.767 & $0.002 *$ \\
\hline
\end{tabular}

Source: Field data, 2016, scale: 1- strongly disagree, 2- agree, 3- neutral, 4 - agree, 5 - strongly agree 
According to Table 6, the most rated challenge to the implementation of IFRS in Ghana is continuous amendment of IFRS and its corresponding effect of amendments of existing accounting practices of business entities to conform to those of IFRS. This is followed by the challenges of using fair value as measurement base, training of relevant accounting professionals in the applications of IFRS, the challenge of accounting knowledge and expertise possessed by financial statement users, compliance and enforcement, complexity of conversion, timely interpretation of standards, funding of conversion, ethical business environment, while the least rated challenge is awareness of international financial reporting practices, followed by taxation related issues, amendment to existing laws, and retention of key employees.

In terms of the difference, there were six areas of difference between the ratings of young and old respondents. Specifically, old accountants rated their perception higher than young accountants under training of relevant accounting professionals in the applications of IFRS, accounting knowledge and expertise possessed by financial statement users, timely interpretation of standards, funding of conversion, retention of key employees, and awareness of international financial reporting practices.

\section{Discussion}

The main purpose of this paper was to examine the views of professional accountants from ICAG regarding the perceived benefits and challenges of IFRS adoption in Ghana since its implementation in 2007. The following sub-sections discuss the main findings of the study to address each research objective of the study.

\subsection{Perceived Benefits of IFRS Adoption in Ghana since Its Implementation in 2007}

The results of this study show that, according to the view of accounting professional of ICAG, the implementation of IFRS in Ghana since 2007 has brought enormous benefits to business entities. Specifically, this study found that accounting professionals perceive that the top most benefit of IFRS adoption to business entities is that the adoption of IFRS has led to easier comparability of financial data across borders, in addition to the elimination of multiple reporting standards, better quality of financial reporting, facilitating easier international mobility of professional staffs across national boundaries, greater transparency and understandability of accounting practices, improved management information for decision-making and better access to capital. Generally, these findings are consistent with those found in past studies (Bhattacharjee \& Hossain 2010; Odia \& Ogiedu, 2013; Owolabi \& Iyoha, 2012; Mihai, Ionaşcu \& Ionaşcu, 2012; Ramanna \& Sletten, 2014; Săcărin et al., 2013). In terms of priority, these findings are consistent with those of Owolabi \& Iyoha (2012), who found that a sample of preparers of financial reports in Africa rated as top benefit of IFRS adoption to business entities the following: ease of using one consistent reporting standard in subsidiaries from different countries, in addition to facilitating mergers and acquisitions, improved management information for decision-making. Thus, Ghanaians business entities have generally benefited from Ghana's adoption of IFRS as a result of normative and mimetic isomorphic pressures (e.g., Ramanna \& Sletten, 2014).

However, the findings of this study also point to some inconsistences with past studies. For example, while this study found that lower cost of audit fees and reduced cost of capital are among the least rated perceived benefit of IFRS in Ghana, these items were highly rated by some financial report preparers in Africa in general in Owolabi \& Iyoha (2012). On the other hand, while this study found better risk management, greater effectiveness of the internal audit as high rated perceived benefits of IFRS adoption in Ghana it was found among the least rated perceived benefits in Owolabi \& Iyoha (2012).

This study's finding on the perceived benefits of IFRS to investors are consistent with many past studies (e.g., Armstrong et al., 2007; Barth et al., 2008; Gordon, 2008). In particular, it confirms the findings of Gordon (2008) and Owolabi \& Iyoha (2012) who listed the benefits from adoption of IFRS over the world to include: companies can be compared to a peer group of companies, better information for decision-making. more confidence in the information presented, better understanding of risk and return, more timely financial reports, easier access to financial reporting, better financial information for shareholders and regulators, enhanced comparability, improved transparency of results, increased ability to secure cross-border listing, better management of global operations and decreased cost of capital.

For investors, this study found that the second and third highest perceived benefit of IFRS adoption to investors in Ghana is that investors have more confidence in the information presented in financial reports prepared in line with IFRS, and companies can be compared to a peer group of companies. These were also highly rated by financial report preparers in the findings of Owolabi \& Iyoha (2012). However, this study found that the highest rated perceived benefit of IFRS adoption to investors in Ghana was better information for decision-making, but it was 
found to be the least rated perceived benefit to investors in Owolabi \& Iyoha (2012).

For policy makers, this study found that IFRS adoption in Ghana has enabled policy makers to benefit mostly from obtaining better information for control and decision-making purposes, promotion of cross-border investment and better access to the global capital markets. Related relevant previous studies, these findings are consistent with those of Owolabi \& Iyoha (2012) who found promotion of cross-border investment and better access to the global capital markets to be among the most important perceived benefits of IFRS adoption to policy makers in Africa by accounting professionals. Similarly, both in this study and that of Owolabi \& Iyoha (2012), the least rated perceived benefit to policy makers was that IFRS adoption facilitates more realistic planning experiences.

However, the top most rated benefit to policy makers in this study was that it enables policy makers to obtain better information for control and decision-making purposes. This finding contracted those of Owolabi \& Iyoha (2012) as it was among the least rated perceived benefit of IFRS to policy makers according in their study.

For national regulatory bodies, this study found that IFRS adoption in Ghana has enabled regulatory bodies by having a higher standard of financial disclosure from business entities, there is better information for market participants, it has enabled their regulatory oversight and enforcement of accounting standards, and enhanced their ability to attract and monitor listing by foreign companies in Ghana. These findings are consistent with those of past studies (e.g., Owolabi \& Iyoha, 2012).

\subsection{Perceived Challenges of IFRS Adoption in Ghana since Its Implementation}

The results of this study show that, according to the view of accounting professional of ICAG, the implementation of IFRS in Ghana since 2007 has brought some teething challenges that calls for immediate attention and strategy from stakeholders. It was found that the most prominent perceived challenge is continuous amendment of IFRS and its attendant effect in the continuous amendments of existing accounting practices of business entities to conform to those of IFRS. This poses a challenge to the benefit of comparability which is a major thrust of IFRS adoption by nations (e.g., Armstrong et al., 2007; Barth et al., 2008; Gordon, 2008; Odia \& Ogiedu, 2013; Hail et al., 2010). It has long been noted that the application of IFRS will not be uniform (Ball, 2006), and that comparability is unlikely to arise from IFRS adoption (Ball, Robin \&Wu, 2003, Christensen Lee \& Walker 2008, Sunders, 2010). Specifically, Ball (2006) observed that "internationalization will reduce some or much of the diversity in accounting rules and practices across nations, it will not eliminate it".

This study also found other top challenges, apart the continuous amendment to IFRS, such as using fair value as measurement base, training of relevant accounting professionals in the applications of IFRS, the challenge of accounting knowledge and expertise possessed by financial statement users.

Accounting professional in ICAG believes training of relevant accounting and accounting knowledge and expertise possessed by financial statement users are two teething challenges that are strongly perceived in the implementation of IFRS in Ghana since 2007. This is to be expected, especially in African countries where there are not enough trained and professional accountants. However, this finding contradicts the findings of Owolabi and Iyoha (2012), who found that both financial prepares and users in their study in Africa rated training of accounting professional to be the least challenge that should be expected with the adoption of IFRS by African countries. Owolabi and Iyoha (2012) noted this surprising results in their study. One would have expected training to create the greatest obstacle especially in the issue of first time adoption of IFRS.

Other challenges found in this study are compliance and enforcement, complexity of conversion, timely interpretation of standards, funding of conversion, ethical business environment, while the least rated challenge is awareness of international financial reporting practices, followed by taxation related issues, amendment to existing laws, and retention of key employees. Some of these results are consistent with some past studies (Bhattacharjee \& Hossain 2010; Essien-Akpan, 2011; Odia \& Ogiedu, 2013; Okere, 2009; Okundi, 2013; Young \& Guenther, 2008).

\subsection{Differences between Young and Old Accounting Professionals in ICAG}

This study found that there were few areas of differences in the evaluation of the perceived benefit and challenges of IFRS adoption by young and old accounting professionals of ICAG. First, young accountants perceive the adoption of IFRS in Ghana to have resulted in elimination of multiple reporting standards significantly higher than old accountants do. Again, young accountants perceive that IFRS adoption has led to facilitating easier international mobility of professional staffs across national boundaries significantly more than old accountants do. Finally, it was found that young accountants perceive that IFRS adoption has led to ease of cross border listing more than old accountants do. Young accountants believe that adoption has resulted in better access to global capital markets than old accountants do. 
In terms of differences in the perceived challenges of IFRS adoption in Ghana, old accountants rated their perception higher than young accountants in training of relevant accounting professionals in the applications of IFRS, the challenge of accounting knowledge and expertise possessed by financial statement users, timely interpretation of standards, funding of conversion, retention of key employees, and awareness of international financial reporting practices.

\section{Implications of Findings}

This study has theoretical, practical and policy implications for the effective collaborative management of IFRS by stakeholders in Ghana.

\subsection{Theoretical Implications}

Theoretically, in view of the generally limited empirical evidence in the IFRS research in developing countries and Ghana particular, this study makes an important contribution to the IFRS literature by providing some of the first empirical study on the perceived benefits and challenges of IFRS adoption in developing countries in general, and Ghana in particular. It especially provides empirical findings from the views of chartered accountants of ICAG as a key stakeholder group in the adoption and implementation of IFRS in Ghana.

Moreover, for scholars interested in IFRS research, this study has confirmed that institutional theory of the adoption of IFRS is applicable in the Ghanaian context, and that by sharing the collective value of IFRS, stakeholders of IFRS such as companies, investors, policy makers, and national regulators stand to benefit immensely from the normative pressures that necessitated the adoption of IFRS by Ghana. In addition to this, the study has highlighted that the perceived benefits and challenges of adoption of IFRS are similar across countries, and Ghana is no exception, confirming several past studies on benefits of IFRS (e.g., Bhattacharjee \& Hossain 2010; Mihai et al., 2012; Odia \& Ogiedu, 2013), challenges of IFRS (e.g., Ball, 2006; Barth et al., 2008; ; Monisola, 2013; Zakari, 2014).

\subsection{Practical and Policy Implications}

To practitioners, in this study the most prominent perceived challenge identified in this study is continuous amendment of IFRS. Therefore, companies, investors, policy makers and national regulators should work together towards developing a framework for managing the dynamics of continuous amendments of IFRS, especially to the reporting and interpretation of existing financial reports within the context of newly approved IFRS amendments. In particular, As IFRS are amended as and when necessary, stakeholders should be ready and prepared to adopt the changes within a pre-determined accounting framework that prevents serious conversion and transitional problems from existing to newly developed standards.

Stakeholders need to put in adequate measures to increase training of relevant accounting professionals in the applications of IFRS. In this regard, it is suggested that accounting and financial management educators should focus on developing curricula that incorporates the IFRS into the content of accounting programmes at all relevant levels of education in Ghana. While the formal education approaches are important, formal and informal training avenues should be used to raise awareness of IFRS among non-professional accounting personnel, especially in the information sector of the economy. In particular, accounting education and training programmes for professional and non-professional accountant staff should emphasise the complexity of fair value as it was found to be the second most rated challenge with IFRS adoption in Ghana, according to ICAG professionals. The complexity that come with the use of fair value, which is IFRS 13, as bases for measurement in financial reporting has attracted a lot of attention by scholars and practitioners, as measurement base is another important challenge, especially in financial reporting. Therefore, more education and training emphasis in this area will enhance accountants' expertise in overcoming the challenges that come with fair value.

Again, there is the need for stakeholders to organise periodic education and training avenues to help users of accounting information/financial statements to increase accounting knowledge and expertise regarding reporting standards. Users of accounting and financial reports might not be experts in the field of accounting and therefore would need more training programmes to enhance their understanding of IFRS-based accounting reports in Ghana.

\section{Conclusions and Limitations}

In conclusion, this study has attempted to provide an initial evidence of the perceived benefits and challenges of IFRS adoption in Ghana, using a cross-sectional sample of ICAG members. In view of the fact that, the ICAG continues to be a strong regulator of accounting practices in Ghana, and a facilitator of IFRS implementation in Ghana since its adoption in 2007, the views of ICAG members on the IFRS adoption provide empirically and practically useful information to stakeholder of IFRS for different purposes. This study found that a number of 
perceived benefits and challenges of IFRS adoption in Ghana, notable among the benefits was the ease of comparability of financial data across border, and the top most challenge was the continuous amendments to IFRS. There were few differences in evaluation between old and young accountants among the respondents.

The main limitation of this study is that it is focused on the context of Ghana. It is expected that future research will provide comparative analysis of perceived benefits and challenges of IFRS adoption in multiple countries in Sub-Saharan African in order to enhance our understanding of similarities and differences in IFRS adoption across African countries.

\section{References}

Aboagye-Otchere, F., \& Agbeibor, J. (2012). The International Financial Reporting Standard for Small and Medium-sized Entities (IFRS for SMES). Journal of Financial Reporting and Accounting, 10(2), 190-214. https://doi.org/10.1108/19852511211273723

Agyei-Mensah, B. K. (2012). Association between firm-specific characteristics and the levels of disclosure of financial information of rural banks in the Ashanti Region of Ghana. Journal of Applied Finance \& Banking, 2(1), 69-92.

Agyei-Mensah, B. K. (2013). Adoption of International Financial Reporting Standards (IFRS) in Ghana and the Quality of Financial Statement Disclosures. International Journal of Accounting and Financial Reporting, 3, 269-286. https://doi.org/10.5296/ijafr.v3i2.4489

Ahmed, A. S., \& Duellman, S. (2011). Evidence on the role of accounting conservatism in monitoring managers' investment decisions. Accounting and Finance, 51(3), 6090-633.

Alp, A., \& Ustuntag, S. (2009). Financial reporting transformation the experience of Turkey. Critical Perspective on Accounting, 20, 680-699. https://doi.org/10.1016/j.cpa.2007.12.005

Amoako, G. K., \& Asante, S. (2012). Compliance with International Financial Reporting Standard 7 (IFRS 7): A Study of Listed Banks in Ghana. Research Journal of Finance and Accounting, 3(4), 66-73.

Armstrong, C. S., Barth, M. E., Jagolinzer, A. D., Riedl, E. J. (2007). Market reaction to the adoption of IFRS in Europe.

Ball, R. (2006). IFRS: Pros and Cons for Investors. Accounting and Business Research International Accounting Policy Forum, 5-27. https://doi.org/10.1080/00014788.2006.9730040

Ball, R., Robin, A., \& Wu, J. S. (2003). Incentives versus standards: Properties of accounting income in four East Asian countries. Journal of Accounting and Economics 36, 235-270

Barth, M., Landsman W., \& Lang, M. (2008). International Accounting Standards and Accounting Quality. Journal of Accounting Research, 46(3), 467-498. https://doi.org/10.1111/j.1475-679X.2008.00287.x

Bhattacharjee, S., \& Hossain, M. S. (2010). Determinants of financial reporting outcomes following IFRS adoption-implications for Bangladesh. Retrieved 20 March 2017, from http://www.icab.org.bd/journal/61.pdf

Boateng, A.A., Arhin, A.B., \& Afful, V. (2014). International Financial Reporting Standard's (IFRS) Adoption in Ghana: Rationale, Benefits and Challenges. Journal of Advocacy, Research and Education, 1(1).

Bohušová, H., \& Blašková, V. (2011). In What Ways are Countries Which Have Already Adopted IFRS for SMEs Different. Acta Universitatis Agriculturae Et Silviculturae Mendelianae Brunensis, 4(2), 37-41.

Bushman, R., \& Piotroski J. (2006). Financial reporting incentives for conservative accounting: The influence of legal and political institutions. Journal of Accounting \& Economics, 42, 107-148. https://doi.org/10.1016/j.jacceco.2005.10.005

Carpenter, V. L., \& Feroz, E. H. (2001). Institutional theory and accounting rule choice: an analysis of four US state governments' decisions to adopt generally accepted accounting principles. Accounting, organizations and society, 26(7), 565-596. https://doi.org/10.1016/S0361-3682(00)00038-6

Christensen, H., Lee, E., \& Walker, M. (2008). Incentives or Standards: What Determines Accounting Quality Change Around IFRS Adoption? Working paper (University of Manchester).

Covaleski, M.A., \& Dirsmith, M.W. (1995). The preservation and use of public resources: transforming the immoral into the merely factual. Accounting, Organizations and Society, 20(2/3), 147-73.

Danaher, P. J., \& Haddrell, V. (1996). A comparison of question scales used for measuring customer satisfaction. 
International Journal of Service Industry Management, 7(4), 4-26. https://doi.org/10.1108/09564239610129922

Daske, H, Hail, L, Leuz, C., \& Verdi R. (2008). Mandatory IFRS reporting around the World: Early Evidence on the Economic Consequences. Retrieved June 14, 2017, from http://ssrn.com

Daske, H., Hail, L., Leuz, C., \& Verdi R. (2008). Mandatory IFRS Reporting Around the World: Early Evidence on the Economic Consequences. Working paper, University of Chicago, Graduate School of Business.

DeFond, M., Hu, X., Hung, M., \& Li, S. (2011). The impact of mandatory IFRS adoption on foreign mutual fund ownership: The role of comparability. Journal of Accounting and Economics, 51(3), 240-258. https://doi.org/10.1016/j.jacceco.2011.02.001

DiMaggio, P., \& Powell, W. W. (1991). The new institutionalism. In Florou, A., Pope, P.F. (2012), Mandatory IFRS Adoption and Institutional Investment Decisions. The Accounting Review, 87(6), 1993-2025.

Essien-Akpan, I. (2011). The International Financial Reporting Standards (IFRS). The Role of the Chartered Secretary and Administrator. A paper presented at the 35th Conference of ICSAN (Lagos Sheraton Hotels and Towers).

Gaston, S. C., Garcia, C. F., Jame, J.I.J., \& Gadea, J.A.L. (2010). IFRS adoption in Spain and the United Kingdom: Effects on accounting numbers and relevance. Advances in Accounting, 26(2), 304-3013. https://doi.org/10.1016/j.adiac.2010.08.003

Girbina, M., Mihaela, M.I.N.U., Bunea, S., \& Sacarin, M. (2012). Perceptions of preparers from Romanian banks regarding IFRS application. Accounting and Management Information Systems, 11(2), 191-208.

Gordon, E.A. (2008). Sustainability in Global Financial Reporting and Innovation in Institutions. Accounting Research Journal, 21(3), 231-238. https://doi.org/10.1108/10309610810922486

Guler, I., Guillen, M., \& Macpherson, J. (2002). Global competition, institutions, and the diffusion of organizational practices: The international spread of ISO 9000 quality certificates. Administrative Science Quarterly, 47, 207-232. https://doi.org/10.2307/3094804

Hail, L., Leuz, C. \& Wysocki, P. (2010). Global accounting convergence and the potential adoption of IFRS by the U.S. (Part I): Conceptual underpinnings and economics analysis. Accounting Horizons, 24, 355-394. https://doi.org/10.2308/acch.2010.24.3.355

Hair, J. F., Black, W. C., Babin, B. J., \& Anderson, R. E. (2010). Multivariate Data Analysis. Englewood Cliffs, NJ: Prentice Hall.

Haunschild, P. R. (1993). Interorganizational imitation: the impact of interlocks on corporate acquisition activity. Administrative Science Quarterly, 38(4), 564-92. https://doi.org/10.2307/2393337

Judge, W., Li, S., \& Pinsker, R. (2010) National adoption of international accounting standards: An institutional perspective. Corporate Governance: An International Review, 18(3), 161-174.

Kapoor, B., \& Ruhela, J. (2013). IFRS Implementation -Issues and Challenges for India. International Journal of Business and Management Research, 3(2), 103-106.

Leuz, C., \& Wysocki, P. (2008). Economic Consequences of Financial Reporting and Disclosure Regulation: A Review and Suggestions for Future Research (pp.1-91). Retrieved June 17, 2017, from http://ssrn.com/abstract=1105398

Li, S. (2010). Does mandatory adoption of International Financial Reporting Standards in the European Union reduce the cost of equity capital? The Accounting Review, 85(2), 607-636.

Liu, J., \& Liu, C. (2007). Value relevance of accounting information in different stock market segments: The case of Chinese A-, B-, and H-shares. Journal of International Accounting Research, 6(2), 55-81.

Madawaki, A. (2014). Adoption of International Financial Reporting Standards in Developing Countries: The Case of Nigeria. International Journal of Business and Management, 7(3), 152-161. Retrieved March 10, 2014, from http://www.ccsenet.org/ijbm

Martins, V. W. (2011). Practical Challenges in IFRS Implementation. What Bank Regulators need to know? IFRS International Conference- Nigeria.

Mihai, S., Ionaşcu, M., \& Ionaşcu, I. (2012). Economic benefits of International Financial Reporting Standards (IFRS) adoption in Romania: Has the cost of equity capital decreased? African Journal of Business 
Management, 6(1), 200-205.

Monisola, O. (2013). Challenges of Adoption of International Accounting Reporting Standards in Nigeria: A counsel to Professional Accountants. Journal of Management Policy, 3(5), 10-31.

Mulyadi, M.S., Soepriyanto, G., \& Anwar, Y. (2012). IFRS adoption and taxation issue. International Journal of Arts and Commerce, 1(7), 159-165.

Ocansey, E. O.N.D., \& Enahoro, J. A. (2014). Comparative study of the international financial reporting standard implementation in Ghana and Nigeria. European Scientific Journal (May 2014 ed.), 10(13), 529-546.

Odia, J.O., \& Ogiedu, K.O. (2013). IFRS Adoption: Issues, Challenges and Lessons for Nigeria and other Adopters. Mediterranean Journal of Social Sciences, 4(3), 389-399. https://doi.org/10.5901/mjss.2013.v4n3p389

Okere, E. O. (2009). International Financial Reporting and Accounting Issues: Imperatives of Attainment of Economic Development in Nigeria, ICAN 39 Annual Accountants Conference.

Okundi, B. (2013). Tax Implications of Implementing IFRSs. Price water house Coopers.

Owolabi, A., \& Iyoha, F. O. (2012). Adopting International Financial Reporting Standards (IFRS) in Africa: benefits, prospects and challenges. African Journal of Accounting, Auditing and Finance, 1(1), 77-86.

Price Water House Coopers. (2010). International financial reporting standards adoption by country. Retrieved October 8, 2010, from www.pwc.com/us/en/issues/ifrs-reporting/assets/ifrs-country-adoption

Ramanna, K., \& Sletten, E. (2014). Network effects in countries' adoption of IFRS. The Accounting Review, 89(4), 1517-1543. https://doi.org/10.2308/accr-50717

Săcărin1, M., Bunea, Ş., \& Gîrbină M. M. (2013). Perceptions of accounting Professionals on IFRS application at The individual financial statements: Evidence from Romania. Accounting and Management Information Systems, 12(3), 405-423.

Samaha, K., \& Khlif, H. (2016). Adoption of and compliance with IFRS in developing countries: A synthesis of theories and directions for future research. Journal of Accounting in Emerging Economies, 6(1), 33-49.

Singh, R. D., \& Newberry, S. (2008). Corporate governance and International Financial Reporting Standard (IFRS): The case of developing countries, in Mathew Tsamenyi, Shahzad Uddin (ed.) Corporate Governance in Less Developed and Emerging Economies. Research in Accounting in Emerging Economies, 8, 483-518.

Straub, D., Boudreau, M. C., \& Gefen, D. (2004). Validation Guidelines for IS Positivist Research. Communications of the AIS, 13(24), 380-427.

Sunder, S. (2010). IFRS Monopoly: The Pied Piper of Financial Reporting, being paper prepared for information for better markets conference ICAEW, London December 20-21, 2010

United Nations. (2007). International Accounting and Reporting Issues. United Nations Review, 2007.

United Nations. (2008). Accounting and Financial Reporting Guidelines for Small and Medium-sized Enterprises (SMEGA) - Level 3 guidance. Retrieved March 26, 2014, from http://www.unctad.org/en/docs/c2isard50_en.pdf

Wei, Y., Liu, X., Song, H., \& Romilly, P. (2001). Endogenous innovation growth theory and regional income convergence in China. Journal of International Development, 13(2), 153-168. https://doi.org/10.1002/jid.721

Yiadom, E. M., \& Atsunyo W. (2014). Compliance with International Financial Reporting Standards by Listed Companies in Ghana. International Journal of Business and Management, 9(10), 87- 100.

Young, D., \& Guenther, D. A, (2008). Financial reporting environments and international capital mobility, Journal of Accounting Research, 41, 553-579. https://doi.org/10.1111/1475-679X.00116

Zakari, M. A. (2014). Challenges of International Financial Reporting Standards (IFRS) Adoption in Libya. International Journal of Accounting and Financial Reporting, 4(2), 390-412.

Zaman, M. M., \& Shiraz, R. A. (2005). The adoption of international accounting standards in Bangladesh: An exploration of rationale and process. Accounting, Auditing \& Accountability Journal, 18(6), 816-841.

Zori, S. (2011). International Financial reporting standards in the African continent: a look at Ghana. Retrieved 18 June 2017, from http://solos-in-african-continent-look-at-ghana.html 